\title{
Pemberdayaan Kelompok Wanita Tani Sekar Makaryo Desa Blayu Kecamatan Wajak Kabupaten Malang Melalui Diversifikasi Kerajinan Mendong
}

\author{
Taufikkurrahman ${ }^{1}$, Erna Atiwi Jaya Esti ${ }^{2}$, Wirawan ${ }^{3}$ \\ ${ }^{1}$ Program Studi Teknik Sipil, Fakultas Teknik, Universitas Wisnuwardhana - Malang \\ ${ }^{2}$ Program Studi Akuntansi, Fakultas Ekonomi dan Bisnis, Universitas Wisnuwardhana - Malang \\ ${ }^{3}$ Program Studi Teknik Industri, Fakultas Teknik, Universitas Wisnuwardhana - Malang \\ E-mail : taufikkurrahman73@gmail.com. 089685676378
}

\begin{abstract}
ABSTRAK
Kelompok Wanita Tani Sekar Makaryo (KWT) adalah sekumpulan wanita tani di desa Blayu yang memiliki usahatani tanaman mendong dan kerajinan mendong dari bahan upkiran. Mendong upkiran selama ini hanya bisa dibuat menjadi tikar dan tali tampar dengan harga jual yang murah. Kemampuan, keterampilan dan ketersediaan peralatan penunjang kerajinan yang dimiliki anggota KWT Sekar Makaryo sangat terbatas sehingga KWT Sekar makaryo belum berani berinovasi untuk pengembangan kerajinan mendong. Program ini bertujuan memberdayakan KWT Sekar Makaryo dalam pengembangan kerajinan mendong melalui diversifikasi produk kerajinan. Metode pelaksanaan dilakukan melalui pelatihan dan pendampingan pengembangan seni kreatif kerajinan mendong menggunakan Alat Tenun Bukan Mesin (ATBM) 6 motif. Hasil dari pelaksanaan program diantaranya adalah peran aktif peserta dalam kegiatan pelatihan, penyuluhan dan pendampingan selama pelaksanaan program yang sangat baik, meningkatnya kemampuan mitra dalam memilih dan memilah serat mendong utuh dan upkiran sebagai bahan baku pembuatan kerajinan mendong, meningkatnya ketrampilan mitra dalam teknik pewarnaan tali serat mendong, dan meningkatnya ketrampilan peserta dalam pengoperasian ATBM 6 motif. Hasil lainnya adalah kegiatan pendampingan yang berjalan efektif serta tersedianya sarana prasarana berupa dua unit ATBM 6 motif dan mesin jahit yang membantu kelompok mitra dalam menghasilkan berbagai motif tenun dan kerajinan mendong seperti tikar, dompet dan sandal.
\end{abstract}

Kata Kunci: diversifikasi; kerajinan; kreatif; mendong

\begin{abstract}
Sekar Makaryo Women's Farmers Group (KWT) is a group of women farmers in the village of Blayu who have a farming plant mendong and crafts mendong from former material. Former mendong so far can only be made into ropes and slaps at low prices. KWT is difficult to innovate for the development of mendong crafts. This program seeks to empower KWT in the development of crafts mendong through diversification of handicraft products. The method of implementation is carried out through training and mentoring the development of creative crafts mendong using 6 motives Non-Weaving Tools (ATBM). The results of the agreed program implementation were the active participation of participants in training, counseling and assistance during the implementation of the program which was very good, mediating the ability of partners to select and sort intact
\end{abstract}

Cara Mengutip : Taufikkurrahman, Esti, E. A. J., Wirawan. (2019). Pemberdayaan Kelompok Wanita Tani

Sekar Makaryo Desa Blayu Kecamatan Wajak Kabupaten Malang Melalui Diversifikasi Kerajinan Mendong. JAST : Jurnal Aplikasi Sains dan Teknologi, 3 (2), 135-145. doi:http://dx.doi.org/10.33366/jast.v3i2.1518 
mendong fibers and upkiran as raw material for making crafts mendong, selection of partners' skills in fiber rope coloring techniques. mendong, and activate the participant's skills in using the ATBM motif 6. Other results are effective mentoring activities and the availability of infrastructure consisting of two ATBM 6 motif units and a sewing machine that helps partner groups in making various motifs, sewing and mending crafts such as gloves, wallet and sandals.

Keywords : diversification; craft; creative; mendong

\section{PENDAHULUAN}

Kelompok Wanita Tani Sekar Makaryo merupakan sekumpulan wanita yang berasal dari keluarga petani mendong yang ada di dusun Krajan Desa Blayu Kecamatan Wajak Kabupaten Malang. Kelompok Wanita Tani ini didirikan sebagai inisiatif dari para wanita keluarga petani mendong untuk membantu perekonomian keluarga mereka. Hal ini didasari oleh permasalahan klasik yang dijumpai dipedesaan bahwa tenaga kerja laki-laki di bidang pertanian yang semakin berkurang karena banyak yang memilih bekerja di kota. Sehingga yang banyak mendominasi hanyalah kaum tua yang bekerja di lahan-lahan pertanian di pedesaan. Kegiatan rutin yang umum dilakukan oleh KWT Sekar Makaryo selama ini adalah penyiapan input produksi seperti penyiapan bahan baku pembibitan tanaman mendong, pengolahan lahan, pemeliharaan tanaman mendong hingga membantu suami mereka dalam hal pemanenan. Kegiatan pascapanen pada mendong masih terbatas pada pengolahan mendong upkiran menjadi tali dan tikar. Kegiatan yang dijalankan oleh Kelompok Wanita Tani Sekar Makaryo tersebut tergolong sederhana, dimana fokus kegiatan mereka lebih dititikberatkan pada kegiatan usahatani mendong on farm.
Usaha tani padat karya yang dijalankan melibatkan anggota keluarga untuk menekan biaya produksi. Meskipun demikian sebagian besar keluarga petani mendong masih sering mengeluhkan sulitnya pengembangan penjualan produk mendong mereka. Selama ini mendong dijual dalam bentuk ikatan mentah untuk bahan baku kerajinan mendong, dengan harga ukuran panjang $60-150 \mathrm{~cm}$ dalam ikatan kecil (sebesar kepalan/ genggaman tangan) sekitar Rp. 12.000,- per ikat dan jika dijual dalam ikatan besar berisi sekitar 10 ikatan kecil biasanya laku Rp 80.000,- sampai Rp. 90.000,-. Jika ratarata petani mendong mampu menjual sekitar 10- 20 ikatan besar maka rata-rata pendapatan yang diperoleh sekitar $\mathrm{Rp}$. 900.000,- hingga Rp. 1.800.000,- setiap kali panen. Sementara itu untuk dapat memanen tanaman mendong, petani harus menunggu sekitar 4-5 bulan. Meskipun petani dapat memanen mendong 7 hingga 8 kali panen tanpa harus mengeluarkan biaya awal produksi, namun petani tetap harus menunggu masa antar panen yang cukup lama sekitar 4 bulan untuk dapat memanen kembali mendongnya.Sehingga jika dibandingkan dengan standar hidup layak di Kabupaten Malang yang mencapai sekitar Rp. 2.200.000,- per bulan, maka pendapatan petani mendong masih jauh dari standar untuk hidup layak. Dari sebab itulah KWT Sekar Makaryo berupaya untuk meningkatkan peran 
mereka dalam membantu perekonomian keluarga. Disela-sela kegiatan produksi di ladang mendong, dan disela-sela masa tunggu panen mendong, beberapa anggota KWT ada yang mengumpulkan dan menyatukan helaian-helaian mendong upkiran (ukuran panjang mendong kurang dari $60 \mathrm{~cm}$ ) yang tidak laku dijual di pasar dalam bentuk ikatan panjang, kemudian beberapa anggota kelompok yang memiliki alat penganyam sederhana menganyam mendong upkiran tersebut menjadi tikar mendong sederhana. Tikar mendong yang dihasilkan, selanjutnya dijual bersamaan dengan ikatan mendong mentah, dan beberapa juga ada yang menjual dalam bentuk olahan setengah jadi berupa tali atau tampar mendong.

Permasalahannya yang dihadapi adalah kemampuan, keterampilan dan ketersediaan peralatan penunjang kerajinan yang dimiliki anggota KWT Sekar Makaryo sangat terbatas. Anggota KWT Sekar makaryo juga belum berani berinovasi untuk pengembangan kerajinan mendong mereka. Secara umum juga diketahui bahwa tikar mendong yang diproduksi dengan cara tradisional sedikit mengalami kesulitan untuk menghasilkan berbagai motif karena terbentur kemampuan peralatan tenun dan mesin jahitnya (Anonymous, 2015). Produk tikar dan tali tampar mendong yang mereka hasilkan hanya dijual di pasar tradisional Senin Pagi di kecamatan Wajak dan dibeli oleh tengkulak dengan harga yang rendah.

Program ini bertujuan untuk memberdayakan KWT Sekar Makaryo melalui peningkatan kemampuan dan keterampilan serta pengelolaan usaha kerajinan mendong. Peluang pengembangan kerajinan mendong $\mathrm{di}$ kabupaten Malang cukup tinggi, karena mendong merupakan salah satu produk unggulan dan produk khas Kabupaten Malang (Abdillah dan Prayitno, 2010). Selain itu daerah Wajak dikenal sebagai daerah sentra produksi tanaman mendong, sehingga upaya pengembangan kerajinan mendong di kecamatan Wajak didukung oleh ketersediaan bahan baku yang melimpah (Pemkab Malang, 2011).

\section{METODE KEGIATAN}

Program pengabdian masyarakat ini dilaksanakan di desa Blayu dan desa Wajak Kecamatan Wajak Kabupaten Malang. Metode pelaksanaan yang diterapkan untuk aspek peningkatan produksi kerajinan mendong, adalah melalui pelatihan dan pendampingan pengembangan seni kreatif kerajinan mendong menggunakan Alat Tenun Bukan Mesin (ATBM) 6 motif. Sementara untuk pemasaran produk kerajinan dan peningkatan kemampuan SDM dalam pengelolaan usaha maka dilakukan pelatihan manajemen usaha. Metode pelaksanaan dari program ini diuraikan sebagai berikut:

1. Pelatihan pengembangan produk kreatif kerajinan mendong dengan Alat Tenun Bukan Mesin (ATBM) 6 motif. Pelatihan ini diisi dengan pemberian materi dan praktek mulai dari:

1) Penyediaan bahan baku meliputi pemilihan, pemilahan dan perlakuan bahan mendong yang digunakan sebagai bahan baku kerajinan mendong;

2) Pelatihan teknik pembuatan kerajinan mendong dengan berbagai desain dan motif. Pelatihan ini meliputi teknik pewarnaan pada 
mendong baik dengan pewarna bahan sintetis maupun pewarna alami untuk menghasilkan beberapa variasi warna; teknik penjemuran, teknik penenunan menggunakan ATBM 6 motif, hingga proses membuat desain dan motif beberapa produk kerajinan.

2. Pelatihan pengenalan alat dan manual prosedur penggunaan Alat Tenun Bukan Mesin (ATBM) 6 motif.

3. Pelatihan Manajemen Usaha, meliputi:

1) Pembentukan kepribadian

2) Ketrampilan berwirausaha,

3) Kalkulasi usaha, berisi materi tentang modal usaha, penentuan harga jual,dan cash flow.

4. Pendampingan pembuatan berbagai produk kreatif kerajinan mendong dengan aneka desain dan motif.

5. Partisipasi mitra, mitra akan terlibat aktif baik dalam kegiatan pelatihan maupun pendampingan sesuai dengan rangkaian program yang telah disepakati bersama.

\section{KARYA UTAMA}

Pelaksanaan program pengabdian bagi KWT Sekar Makaryo telah menghasilkan beberapa kegiatan dan produk usaha kreatif yang tersaji secara ringkas pada Tabel 1 .

Tabel 1. Hasil Pelaksanaan Program

\begin{tabular}{|c|c|c|}
\hline No. & Uraian Kegiatan & Capaian Hasil \\
\hline 1 & $\begin{array}{l}\text { Penyediaan bahan } \\
\text { baku meliputi; } \\
\text { Pelatihan teknik } \\
\text { pembuatan } \\
\text { kerajinan } \\
\text { mendong dengan } \\
\text { berbagai desain } \\
\text { dan motif. }\end{array}$ & $\begin{array}{l}\text { Seluruh peserta } \\
\text { mampu memilih } \\
\text { dan memilah bahan } \\
\text { baku mendong, dan } \\
\text { membedakan serat } \\
\text { mendong utuh dan } \\
\text { upkiran. }\end{array}$ \\
\hline
\end{tabular}

\begin{tabular}{|c|c|c|}
\hline 2 & $\begin{array}{l}\text { Pelatihan } \\
\text { pewarnaan pada } \\
\text { bahan baku } \\
\text { mendong dan } \\
\text { teknik penenunan } \\
\text { dengan ATBM }\end{array}$ & $\begin{array}{l}\text { Pengenalan } \\
\text { pewarna bahan } \\
\text { sintetis maupun } \\
\text { pewarna alami } \\
\text { untuk menghasilkan } \\
\text { beberapa variasi } \\
\text { warna, teknik } \\
\text { penjemuran, sampai } \\
\text { siap untuk ditenun. } \\
\text { Teknik penenunan } \\
\text { menggunakan } \\
\text { ATBM } 6 \text { motif, } \\
\text { hingga proses } \\
\text { membuat desain } \\
\text { dan motif beberapa } \\
\text { produk kerajinan }\end{array}$ \\
\hline 3 & $\begin{array}{l}\text { Pelatihan } \\
\text { pengenalan alat } \\
\text { dan manual } \\
\text { prosedur } \\
\text { penggunaan Alat } \\
\text { Tenun Bukan } \\
\text { Mesin (ATBM) } 6 \\
\text { motif }\end{array}$ & $\begin{array}{l}70 \% \text { Peserta } \\
\text { mampu mengenali } \\
\text { alat dan mengerti } \\
\text { manual prosedur } \\
\text { penggunaan alat } \\
\text { tenun bukan mesin } \\
\text { (ATBM) } 6 \text { motif } \\
\text { dengan baik, } \\
\text { sementara sebagian } \\
\text { kecil masih belum } \\
\text { bisa menggunakan } \\
\text { ATBM }\end{array}$ \\
\hline 4 & $\begin{array}{l}\text { Pendampingan } \\
\text { pembuatan } \\
\text { berbagai produk } \\
\text { kreatif kerajinan } \\
\text { mendong dengan } \\
\text { aneka desain dan } \\
\text { motif }\end{array}$ & $\begin{array}{l}\text { Peserta secara } \\
\text { umum adalah } \\
\text { kelompok pemula, } \\
\text { dengan } \\
\text { pendampingan } \\
\text { selama satu bulan } \\
\text { memberikan hasil } \\
\text { signifikan } \\
\text { meningkatkan } \\
\text { ketrampilan mitra. } \\
70 \% \text { peserta yang } \\
\text { mampu } \\
\text { mengoperasikan } \\
\text { alat tenun mampu } \\
\text { membuat kerajinan } \\
\text { mendong berupa } \\
\text { tikar, dompet, } \\
\text { sandal }\end{array}$ \\
\hline 5 & $\begin{array}{l}\text { Evaluasi terhadap } \\
\text { partisipasi mitra }\end{array}$ & $\begin{array}{l}\text { Seluruh peserta } \\
\text { terlibat aktif dalam } \\
\text { kegiatan pelatihan } \\
\text { maupun } \\
\text { pendampingan } \\
\text { sesuai dengan } \\
\text { rangkaian program } \\
\text { yang telah } \\
\text { ditentukan. }\end{array}$ \\
\hline
\end{tabular}


$\begin{array}{ccc}\text { Usaha kerajinan tikar yang } \\ \text { diproduksi } & \text { KWT Sekar Makaryo }\end{array}$ merupakan peluang bagi keluarga petani mendong untuk pengembangan usaha mendong. Potensi tersebut didapatkan karena bahan baku mendong tersedia melimpah, sehingga mereka tidak kesulitan mendapatkan sumber bahan baku untuk pengembangan kerajinan mendong. Selain itu, mereka juga dapat mengolah satu ikatan besar mendong menjadi berbagai produk kerajinan yang dapat memberikan nilai tambah tanaman mendong dan dapat meningkatkan nilai jual mendong.

Pelaksanaan program kemitraan masyarakat bagi kelompok wanita tani Sekar Makaryo, diawali dengan sosialisasi kegiatan. Kegiatan sosialisasi ini dilakukan sebagai upaya pendekatan secara persuasif kepada mitra agar mempersiapkan diri selama pelaksanaan program. Kegiatan setelah sosialisasi dilanjutkan dengan kunjungan ke beberapa mitra untuk penjajagan ketersediaan bahan baku mendong. Hal ini dilakukan sebelum pelaksanaan pelatihan lanjutan pengenalan dan pengoperasian ATBM. Ketersediaan bahan baku mendong sangat penting untuk mempersiapkan produksi kerajinan. Dalam kesempatan kunjungan tersebut, beberapa kelompok kecil mitra dibekali pengetahuan awal dalam penyiapan bahan baku. Pemilihan dan pemilahan bahan baku antara mendong upkiran dan mending utuh (Gambar 1). Panjang optimal tali mendong yang layak digunakan sebagai bahan kerajinan yaitu sekitar $60 \mathrm{~cm}$ diambil mulai dari ujung pangkal. Hal ini didasarkan hasil penelitian Suryanto et al. (2015) bahwa batang mendong memiliki kekuatan cukup homogen sampai dengan panjang $60 \mathrm{~cm}$ dari pangkal batang dengan koefisien variasi kurang dari $15 \%$ setelah itu kekuatan batang memiliki variasi yang terlalu tinggi (>20\%). Dari hasil tersebut dapat digunakan acuan bahwa untuk memperoleh hasil kekuatan yang homogen maka sebaiknya panjang mendong yang digunakan adalah sampai $60 \mathrm{~cm}$ dari pangkal batang.

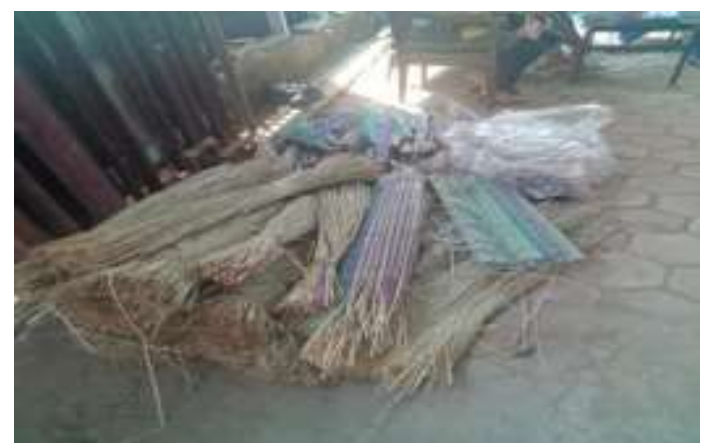

Gambar 1. Bahan baku tali mendong hasil pemilahan dan pewarnaan.

Dua unit Alat Tenun Bukan Mesin (ATBM) 6 motif dan perangkat alat-alat pendukung lainnya telah diserahkan oleh tim pelaksana kepada kelompok mitra (Gambar 2 dan 3). Hasil pelaksanaan program selanjutnya adalah terlaksananya pelatihan pengenalan dan pengoperasian ATBM dan mesin jahit yang dibantu oleh instruktur terlatih (Gambar 4). Kegiatan ini membantu mitra mengenali alat dan cara kerja alat tenun bukan mesin 6 motif.

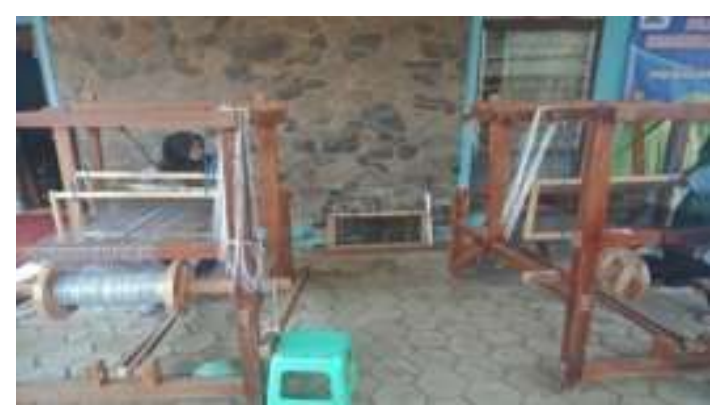

Gambar 2. Dua unit ATBM 6 motif sebagai sarana produksi kerajinan mendong. 


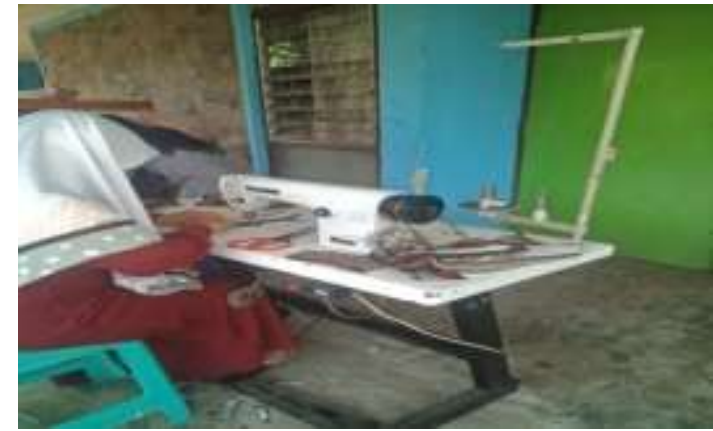

Gambar 3. Satu unit mesin jahit sebagai sarana pendukung proses produksi kerajinan mendong

Alat tersebut membantu mitra dalam proses pelatihan dan produksi kerajinan mendong. ATBM 6 motif membantu mitra untuk menghasilkan anyaman mendong dengan berbagai motif sehingga dapat dijadikan bahan membuat kreasi berbagai kerajinan berbahan mendong. Sementara itu, mesin jahit tindas untuk memperhalus finshing pada proses akhir pembuatan produk kerajinan mendong, benang, pernak-pernik hiasan, dan bahan-bahan penunjang lainnya untuk mempercantik berbagai produk kerajinan yang dihasilkan. Untuk meningkatkan ketrampilan dalam pembuatan kerajinan mendong, program dilanjutkan dengan demoplot atau praktek secara langsung.

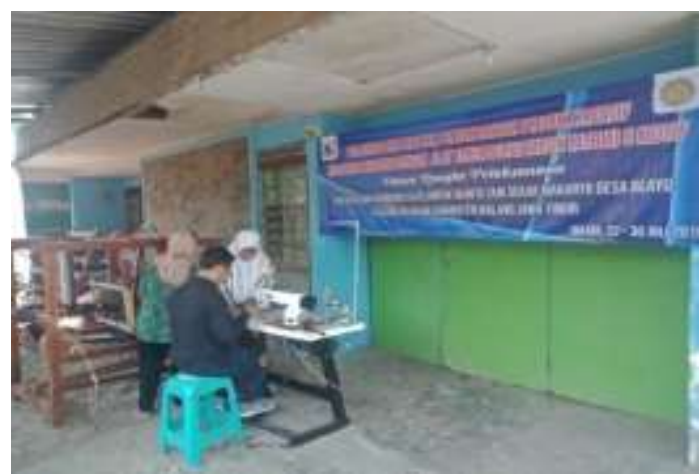

Gambar 4. Pelaksanaan pelatihan pengoperasian ATBM 6 motif pada kelompok mitra.

Demoplot dilakukan di salah satu rumah perwakilan mitra. Praktek diawali dengan pembuatan anyaman dari tali mendong yang telah diwarnai. Beberapa motif mampu dihasilkan oleh mitra (Gambar 5).

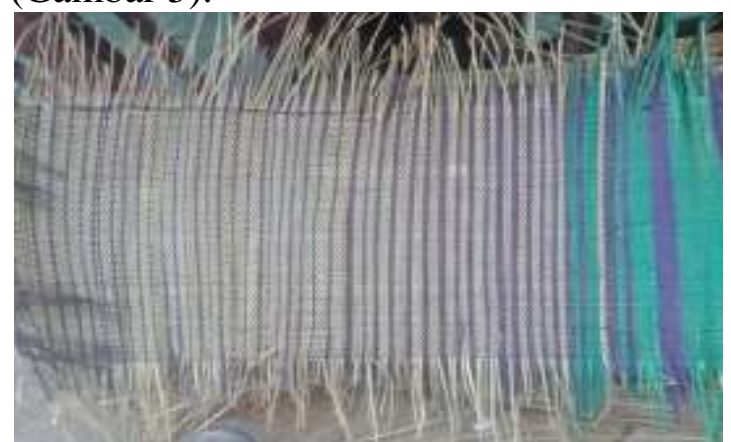

Gambar 5. Hasil anyaman mendong beberapa motif dari peggunaaan alat tenun bukan mesin (ATBM).

Anyaman setengah jadi selanjutnya dijadikan bahan dasar untuk pembuatan kerajinan lainnya. Beberapa peserta yang terbagi dalam beberapa kelompok kecil memiliki kesempatan untuk berbagi tugas. Kelompok bagian satu belajar menganyam dengan menggunakan alat tenun bukan mesin, sementara kelompok dua membantu memperhalus anyaman, disesuaikan dengan tujuan produksi. Untuk pembuatan tikar, dari kelompok dua terlibat memperhalus bagian pinggir tikar menggunakan mesin jahit tindas. Tikar yang telah jadi selanjutnya dijemur di dalam ruang untuk dikeringanginkan beberapa hari sebelum dilakukan pengemasan (Gambar 6).

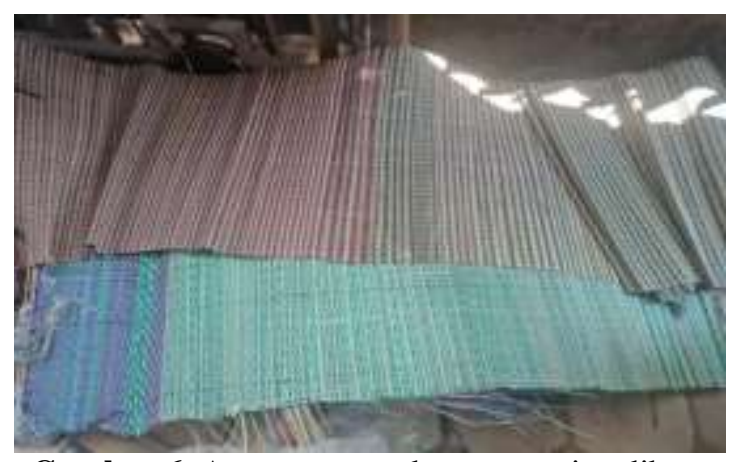

Gambar 6. Anyaman mendong yang siap dibuat kerajinan 
Kelompok tiga selanjutnya didampingi oleh tim pelaksana dan instruktur untuk belajar membuat desain dan pola kerajinan lainnya. Beberapa alat pendukung disediakan oleh tim dan mitra untuk pembuatan desain (Gambar 7). Beberapa pola dan desain kerajinan mampu dihasilkan oleh mitra, diantaranya adalah pola dan desain dompet, tempat tissue dan sandal (Gambar 8).

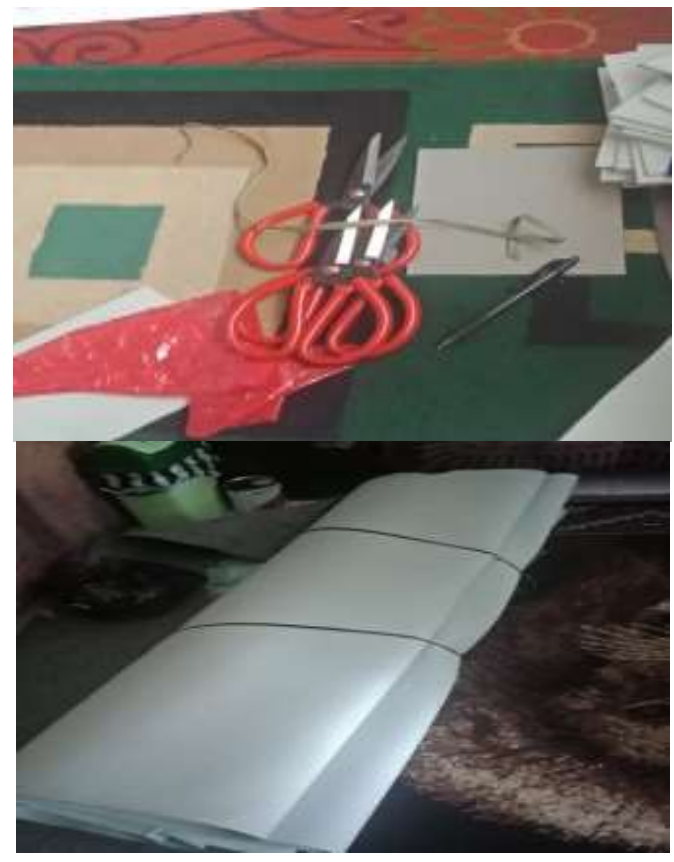

Gambar 7. Alat dan bahan pendukung pembuatan kerajinan mendong

Desain dan pola pembuatan kerajinan berbahan mendong hampir sama dengan pembuatan pola dan desain dari bahan lainnya seperti akar wangi (Haryadi dan Hartono, 2013). Tim pelaksana memberikan berbagai fasilitas pembelajaran dengan tujuan memberikan kesempatan bagi mitra untuk berkreasi menghasilkan berbagai produk kerajinan. Tim juga memberikan kesempatan bagi mitra untuk kegiatan pendampingan baik selama proses produksi hingga pada tahap pemasaran hasil.

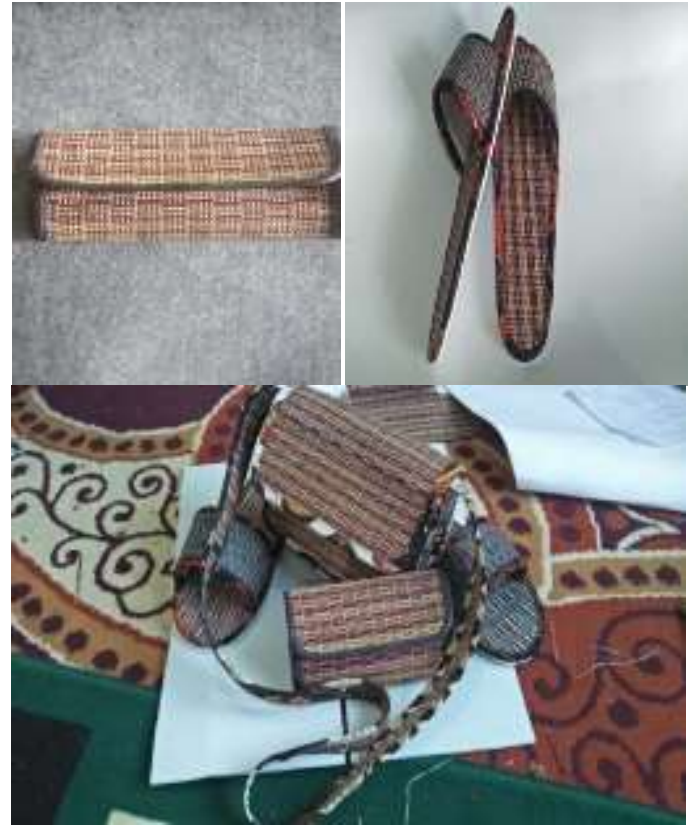

Gambar 8. Berbagai kreasi kerajinan berbahan mendong.

Keterlibatan mitra sangat diperlukan dalam pelaksanaan program (Gambar 9). Dalam pemberdayaan masyarakat, keberhasilan suatu program akan tergantung pada keterlibatan aktif peserta. Hal ini merujuk pada kebijakan pemerintah yang mengubah paradigma pembangunan nasional menjadi pembangunan inklusif sejak terjadinya krisdi moneter pada tahun 1997-1999. Pembangunan inklusif yaitu pembangunan dengan melibatkan semua warga masyarakat dalam berbagai kegiatan ekonomi sesuai dengan keahlian masingmasing (Tambunan, 2016). Disinilah salah satu peran dunia pendidikan sebagai modal Sumber Daya Manusia diharapkan dapat memunculkan inovasi-inovasi yang dapat disebarluaskan melalui program pemberdayaan masyarakat.

Pelatihan manajemen usaha juga diberikan kepada mitra sebagai kegiatan pamungkas untuk pemasraan produk. Peran aktif mitra juga dihandalkan untuk 
dapat memasarkan secara mandiri produk kerajinan yang telah dihasilkan. Jika memungkinkan suatu saat mitra juga diperkenalkan dengan lembaga pembiayaan jika mitra menghendaki pengembangan usaha. Untuk sementara, produk kerajinan seperti tikar, tempat tissue, dompet dan serandal ditampung oleh tim pelaksana bekerjasama dengan koperasi kampus untuk pemasaran hasil.

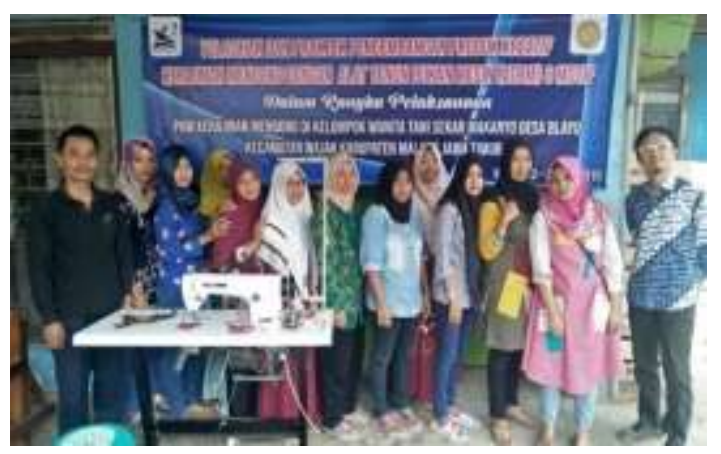

Gambar 9. Kebersamaan Tim pelaksana dan mitra.

Hal terpenting yang ditekankan oleh tim kepada mitra adalah jalinan kebersaman sesama anggota dalam satu kelompok wanita tani Sekar Makaryo, agar sesama anggota dapat berbagi tugas dan menjaga peran satu dengan yang lainnya untuk kesejahteraan semua anggota, karena ini merupakan salah satu komponen penting pada industri kerajinan mendong.

Untuk merangsang kemandirian mitra binaan dibekali pula dengan materi kewirausahaan dan perencanaan bisnis. Agar mereka tidak hanya mahir dalam memproduksi namun juga dapat menyusun usaha yang menguntungkan. Pembekalan selanjutnya adalah materi perencanaan dan pengendalian produksi, perencanaan dan penentuan lokasi usaha, perencanaan produksi, perencanaan kebutuhan bahan baku, penentuan tenaga kerja, kendali mutu dan jaringan proses kerja. Selain memproduksi mitra binaan juga dilatih dalam perhitungan biaya usaha, membuat perencanaan pemasaran, strategi pemasaran dan strategi membuat jaringan dan cara mencari peluang usaha. Mitra dilatih pula dalam membuat kalkulasi modal dan penggalangan dana serta menentukan harga jual dan membuat arus kas (cash flow) (Buchari, 2000; Geoffrey, 2000; Rusman, 1998; Suryana, 2008).

\section{ULASAN KARYA}

Beberapa keunggulan dan kelemahan program pemberdayaan ini perlu dipaparkan agar dapat dikembangkan keunggulannya serta diatasi kendalanya pada program selanjutnya sehingga seluruh permasalahan petani mampu diatasi. Di antara keunggulan seluruh rangkaian kegiatan program pemberdayaan adalah fasilitasi petani dengan ATBM (Alat Tenun Bukan Mesin) dan mesin jahit serta pendampingan oleh instruktur terlatih. Fasilitas ini membantu petani untuk mampu memproduksi anyaman mendong dengan berbagai motif sehingga kerajinan mendong semakin variatif. Mesin jahit tindas berfungsi untuk memperhalus produk kerajinan mendong, benang, pernak-pernik hiasan, dan bahan-bahan penunjang lainnya untuk agar tampak menarik. Demoplot atau praktik langsung dilaksanakan untuk memastikan seluruh peserta pelatihan mampu mengoperasikan alat dan mampu menghasilkan produk sesuai target.

Rangkaian pelatihan ini memiliki beberapa kelemahan di antaranya adalah 
bahwa pelatihan ini hanya menyasar petani dan perajin mendong. Jika kembali pada masa kesuksesannya ketika mendong menjadi salah satu produk ekspor yang cukup diperhitungkan, maka perlu kiranya upaya pelestarian tanaman hingga kerajinan mendong. Secara praktis, pelatihan seharusnya juga menyasar masyarakat secara umum sehingga mereka mengenal, tertarik dan mampu turut serta dalam bagian melestarikan mendong.

Pelatihan ini juga belum melibatkan Dinas Perindustrian, Perdagangan dan Koperasi sehingga peluang keberlanjutan program kecil. Selain itu, pemerintah desa sebagai salah satu pihak yang bisa menggerakkan masyarakat agar berpartisipasi dalam program ini juga belum diikutsertakan. Pelatihan ini juga lemah pada struktur kerangka kegiatan pasca produksi yakni pada optimalisasi pengelolaan pemasaran produk.

\section{DAMPAK DAN MANFAAT KEGIATAN}

Pelatihan ini berdampak secara kualitas yaitu kemampuan petani memproduksi kerajinan mendong dengan motif yang lebih variatif dengan proses finishing lebih halus sebagai hasil penggunaan mesin jahit tindas. Secara keseluruhan, produk kerajinan memiliki added value yang lebih menarik dibandingkan sebelumnya. Pelatihan pengelolaan pemasaran juga membuka cakrawala para peserta tentang berbagai persiapan dan strategi untuk menghadapi globalisasi yang berdampak besar secara langsung terhadap bisnis.

Berdasarkan kajian menyeluruh terhadap potensi produk unggulan daerah dan SDM serta keunggulan, kelemahan dan dampak program pemberdayaan, maka direkomendasikan sebagai rencana tindak lanjut program pemberdayan yang akan datang adalah sebagai berikut :

a. Pengadaan fasilitas pokok perajin mendong untuk peningkatan produktivitas kerja baik secara kualitas maupun kuantitas

b. Pelaksanaan pelatihan pemasaran yang lebih efektif dan efisien yang terstruktur dengan baik

c. Pelaksanaan kerjasama dengan Disperindagkop dan pemerintah desa sebagai ujung tombak keberlanjutan program pemberdayaan, salah satunya sebagai pendukung utama dalam wilayah finansial dan pelaksana fungsi pengawasan.

\section{KESIMPULAN}

Hasil dari pelaksanaan program diantaranya adalah peran aktif peserta dalam kegiatan pelatihan, penyuluhan dan pendampingan selama pelaksanaan program yang sangat baik. Pemberdayaan masyarakat melalui pelatihan dan pendampingan pembuatan berbagai kerajinan berbahan mendong secara nyata mampu meningkatkan kemampuan dan keterampilan mitra diantranya yaitu hampir semua mitra mampu memilih dan memilah serat mendong utuh dan upkiran sebagai bahan baku pembuatan kerajinan mendong, mitra juga mampu mempraktekkan teknik pewarnaan tali serat mendong. Kegiatan pendampingan dapat berjalan efektif dengan tersedianya sarana prasarana berupa dua unit ATBM 6 motif dan mesin jahit membantu 
kelompok mitra dalam menghasilkan berbagai motif tenun dan kerajinan mendong Dan yang utama adalah mitra mampu mengoperasikan ATBM 6 motif sehingga mampu menghasilkan berbagai produk kreatif seperti seperti tikar, dompet, tas dan sandal.

\section{PENGHARGAAN}

Ucapan terimakasih disampaikan kepada Direktorat Riset dan Pengabdian Masyarakat, Direktorat Jenderal Penguatan Riset dan Pengembangan Kementerian Riset, Teknologi dan Pendidikan Tinggi dan LL DIKTI Wilayah VII Jawa Timur atas pembiayaan melalui dana hibah dengan Nomor Kontrak: 060/071028/05.1/IV/2019 sehingga program pengabdian masyarakat ini dapat terlaksana dengan baik.

\section{DAFTAR PUSTAKA}

1. Anonymous, 2015. Produk Unggulan Kabupaten Malang. www.malangkab.go.id/site/read/detail/ 229/produk-unggulan-kabuptenmalang.html diakses tanggal 16 Januari 2016.

2. Abdillah, F.F., Surjono. dan G. Prayitno. 2010. Pengembangan Sentra Agroindustri Kerajinan Mendong Kabupaten Malang dengan Pendekatan Pengembangan Ekonomi Lokal. Jurnal Tata Kota dan Daerah 2(2):31-41.

3. Buchari Alma. 2000. Kewirausahaan, Penerbit Alfabeta, Bandung.

4. Geoffrey G.Meredith, 2000. Penerjemah Andre Asparsayogi,
Kewirausahaan Teori dan Praktek, PT Pustaka Binaman Pressindo. Jakarta.

5. Haryadi, N.K. dan E.T. Hartono. 2013. Kerajinan Akar Wangi. Arcita. Surakarta. 104pp.

6. Hilman I. 2015. Rekayasa Teknologi Mesin Penganyam Mendong dalam Upaya Meningkatkan Produktivitas Industri Tikar Mendong di Kecamatan Purbaratu Kota Tasikmalaya. Prosiding Seminar NasionaInovasi dan Tren. p.109-114

7. Kaleka N. dan E.T. Hartono. 2014. Aneka Kerajinan Mendong. Arcita. Solo. 97pp.

8. Kaleka N. dan E.T. Hartono. 2014. Kerajinan Eceng Gondok. Arcita. Solo. 86pp.

9. Pemerintah Kabupaten Malang. 2011. Peraturan Daerah Kabupaten Malang Nomor: 2 Tahun 2011 tentang Rencana Pembangunan Jangka Menengah Daerah (RP JMD) Kabupaten Malang Tahun 2010-2015. Malang. 151pp.

10. Rusman Hakim, 1998. Dengan Wirausaha Menepis Krisis, PT Elex Media Komputindo. Jakarta.

11. Suryana, 2008. Kewirausahaan : Pedoman Praktis, Kiat dan Proses Menuju Sukses. Salemba Empat. Jakarta.

12. Suryanto, H., Y.S. Irawan, E. Marsyahyo, dan R. Soenoko. 2013. Karakteristik serat mendong (Fimbristylis globulosa): Upaya menggali potensi sebagai penguat komposit matriks polimer. National Conference. Green Technology 3. 
Harmony of technology and Natural. https://www.researchgate.net/publicati on/282735207. $7 \mathrm{pp}$.

13. Utami, K.S. dan N.N. Kurniyati. 2013. Strategi Pengembangan Usaha Kecil Menengah (UKM) Kreatif Pedesaan di Kabupaten Sleman Studi Kasus
Subsektor Industri Kerajinan Anyaman Mendong. Prosiding Seminar Nasional Menuju Masyarakat Madani dan Lestari. Yogyakarta.

14. Tambunan, T. (2016). Pembangunan Ekonomi Inklusif. Jakarta: LP3ES. 